Journal of Agriculture, Food and Environment (JAFE)

Journal Homepage: $\underline{\text { http://journal.safebd.org/index.php/jafe }}$

http://doi.org/10.47440/JAFE.2020.1417

Original Article

\title{
Changes in sensory, biochemical and microbiological parameters of smoked shrimps (both traditional and improved) in different packages at refrigeration temperature (5 to $8^{\circ} \mathrm{C}$ )
}

\author{
M. I. Hossain, F. H. Shikha* and M. M. Islam \\ Department of Fisheries Technology, Bangladesh Agricultural University, Mymensingh-2202, Bangladesh
}

\begin{abstract}
Article History
Received: 06 November 2020

Revised: 12 December 2020

Accepted: 18 December 2020

Published online: 31 December 2020

\section{*Corresponding Author}

F. H. Shikha

E-mail: shikhafh@bau.edu.bd

\section{Keywords}

Smoked shrimp, packaging, refrigeration temperature $\left(5\right.$ to $\left.8^{\circ} \mathrm{C}\right)$, storage, quality change
\end{abstract}

\begin{abstract}
A B S T R A C T
Smoking or smoke curing, like drying and salt curing, is an ancient method of preservation of shrimp. The present experiment was conducted to prepare improved smoked shrimp from four species of shrimps, namely Horina (Metapenaeus monoceros), Chali (Metapenaeus brevicornis), Chaka (Penaeus indicus) and Khogda (Parapenaeopsis stylifera) at laboratory condition to evaluate the changes in senseory, biochemical and microbiological parameters of the both laboratory and traditionally prepared (at Koyra, Khulna) smoked shrimps. For smoking, a locally made smoking kiln was used at laboratory. Then both improved and traditionally prepared smoked shrimps were stored in various packages at refrigeration temperature $\left(5\right.$ to $\left.8^{\circ} \mathrm{C}\right)$. The initial moisture level of improved smoked shrimps (Horina, Chali, Chaka and Khogda) ranged from $14.22 \pm 0.02 \%$ to $16.15 \pm 0.03 \%$ with the highest value in Khogda, but the moisture content of traditionally smoked Chali was $17.53 \pm 0.11 \%$. After long storage of 150 days at refrigeration temperature $\left(5\right.$ to $\left.8^{\circ} \mathrm{C}\right)$, the moisture content was found to be $10.02 \pm 0.03 \%$ to $12.81 \pm 0.03 \%$ for all the stored smoked shrimps. The initial protein content of improved smoked shrimp ranged from $62.15 \pm 1.20 \%$ to $64.05 \pm 0.1 .10 \%$ with the highest value in Chali; whereas the protein content was lower in traditionally smoked Chali which was $61.18 \pm 1.23$ $\%$. During the storage, protein content decreased with the lapse of time and ranged from $52.14 \pm 1.12 \%$ to $54.47 \pm 1.12 \%$. Initial lipid content of improved smoked shrimp ranged from $9.73 \pm 0.95 \%$ to $10.05 \pm 0.05 \%$ and in traditional smoked Chali the value was $9.24 \pm 0.09 \%$. At the end of the storage period, the lipid content of smoked shrimp ranged from $7.65 \pm 0.08 \%$ to $8.75 \pm 0.08 \%$ and in traditional smoked Chali it was $7.69 \pm 0.09 \%$. Ash contents of smoked shrimp increased and ranged from $11.06 \pm 0.14 \%$ to $23.00 \pm 0.21 \%$. The TVB-N value of improved smoked shrimp was significantly lower than that of traditionally prepared smoked shrimp. Initial TVB-N value of improved smoked shrimp ranged from $12.23 \pm 0.12 \mathrm{mg} / 100 \mathrm{~g}$ to $14.05 \pm 0.09 \mathrm{mg} / 100 \mathrm{~g}$ and in traditional smoked Chali the TVB-N value was $15.83 \pm 0.12 \mathrm{mg} / 100 \mathrm{~g}$. With the progress of study period, TVB-N value also increased, which ranged from $25.42 \pm 1.45$ $\mathrm{mg} / 100 \mathrm{~g}$ to $31.14 \pm 0.12 \mathrm{mg} / 100 \mathrm{~g}$. The initial APC of improved smoked shrimp was $4.3 \times 10^{2} \mathrm{CFU} / \mathrm{g}$ to $2.05 \times 10^{3} \mathrm{CFU} / \mathrm{g}$ and in traditionally prepared smoked Chali it was $3.6 \times 10^{3} \mathrm{CFU} / \mathrm{g}$. After the storage period the total bacterial content ranged from $1.67 \times 10^{6} \mathrm{CFU} / \mathrm{g}$ to $6.17 \times 10^{6} \mathrm{CFU} / \mathrm{g}$ for all the stored products. The results obtained in the study showed that the steps followed for smoking of shrimps in the laboratory contributed to improve the quality of smoked shrimps, at the same time smoked shrimps were in better condition in air tight and vacuum packages than the samples stored in non-sealed packages.
\end{abstract}




\section{Introduction}

Shrimp smoking is a processing method of shrimp accomplished by a combination of drying and deposition of naturally produced chemicals resulting from thermal break down of wood or burning of wood. The property of smoked shrimp depends to a large extent on the type of wood from which it is produced. Thermal cracking of wood under reduced oxygen supply results in smoke containing several compounds. The gas phase contains several flavor-producing agents, aliphatic and aromatic, numbering over 200 (Horner, 1992). In modern world smoked fish is a delicacy. On the other hand importance in many countries of central Africa and Middle-eastern Asia are largely a technical necessity rather than delicacy due to dry and less humid climatic conditions and other reasons. In southeastern Asia, smoking is mostly practiced not necessarily to impart desirable color and flavor, but mainly to accelerate the drying of fish (Clucas and Ward, 1996). Various low cost fish processing methods are practiced in Bangladesh such as- drying, salting, smoking etc. For sun drying proper intensity of sunlight is required for producing quality dried products. Salting requires addition of extra capital and labor. Salting is also somewhat species specific and mainly used for fatty fish. But for small shrimps in rainy season smoking is a good technique for preservation and is being used from the time immemorial due to no other alternative methods available in rainy season (Hoq et al. 2006).

Smoking of small fish and shrimp is a profitable business in some coastal part of Bangladesh. (Source: low-cost processing of Fish in Coastal Bangladesh- FAO of the United Nations. BGD/97/017 Field Doc: 5/2005). In Koyra and Paikgacha, the smoked shrimp producers operate their activities all over the year except the months of November, December and January as the raw materials is not available during that time. The smoking activities are closely related with the lunar cycle as the lunar cycle determines the availability of shrimps. The smoked shrimp producer operates smoking process 12 days per month, 6 days during full moon and 6 days during new moon as the shrimps are captured in large amounts. Comparatively, shrimps are more abundant in full moon tide than new moon tide. About 20$30 \%$ of the shrimps caught in coastal region are used for smoke-drying purpose (Hoq et al., 2003). The smoked shrimp producers in Koyra, Khulna uses three species of shrimps, locally called- Chali (Metapenaeus brevicornis), Chaka (Penaeus indicus) and Harina (Metapenaeus monocerus). Sometimes they process by mixing of all the three species. Shrimp naturally contain many parasites. These parasites are killed during the hot-smoking process, if the temperature reaches $60^{\circ} \mathrm{C}$ (Jahncke, 2008).

In recent years, smoked shrimp got much popularity in Bangladesh and have good market in Khulna, Chittagong region. Packaging extends the shelf life of food products by controlling the growth of microorganisms, pathogenic flora and it protects oxidative rancidity of the product. The technology for producing smoked shrimp and packaging of smoked product increase shelf life which require very simple machinery. Successful manufacture and marketing of smoked shrimp ensure the proper utilization of the small shrimp and finally raise the price of the products. Considering these points, the present study aimed to prepare improved smoked shrimp at laboratory condition and to compare the changes in biochemical and microbiological changes in both traditional and improved smoked shrimps at refrigeration temperature $\left(5\right.$ to $\left.8^{\circ} \mathrm{C}\right)$ under different packaging conditions.

\section{Materials and Methods}

The experiment was conducted in the laboratories of Department of Fisheries Technology, Faculty of Fisheries, Bangladesh Agricultural University (BAU), Mymensingh.

\section{Shrimp species:}

Four species of raw shrimps, namely Horina (Metapenaeus monoceros), Chali (Metapenaeus brevicornis), Chaka (Penaeus indicus) and Khogda (Parapenaeopsis stylifera) and traditionally smoked shrimps of same species were purchased from Koyra, Khulna and directly brought to the Fish Processing laboratory of the Department of Fisheries Technology, BAU (Plate-1).

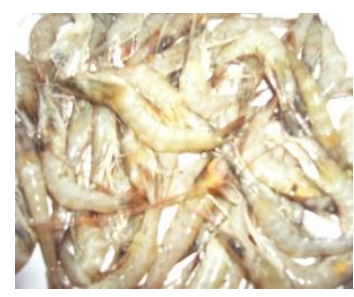

(a)

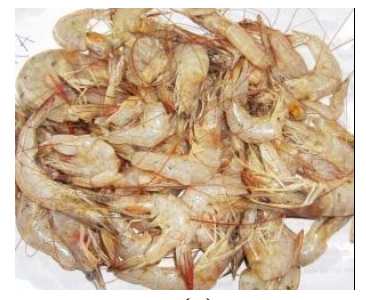

(c)

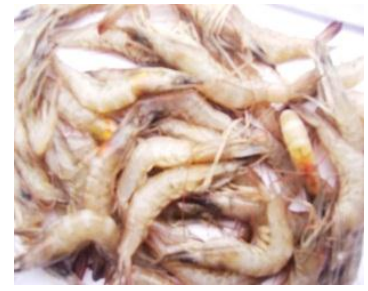

(b)

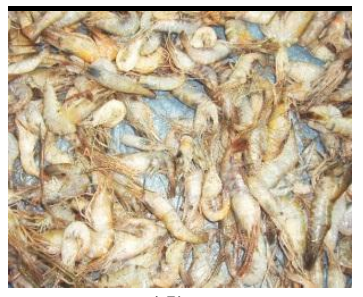

(d)
Plate 1. (a) Horina (Metapenaeus monoceros), (b) Chali (Metapenaeus brevicornis), (c) Chaka (Penaeus indicus) and (d) Khogda (Parapenaeopsis stylifera)

\section{Production of improved smoked shrimp at laboratory condition}

\section{Smoking kiln}

The smoking kiln was made with steel sheet as a rectangular box of $5.2 \times 2.7 \times 2.3 \mathrm{ft}^{3}$ size [Plate-2 (a)]. Horizontally, the box or chamber was divided into two equal parts by using a horizontal steel sheet and the bottom portion was used for burning saw dust as smoke source. The horizontal separator had a central circular hole of 8 inch diameter. The upper chamber had facilities of hanging 4-6mm iron rods supported from two sides as rack. Both the chambers had door which could be opened when needed. On the top, there was an outlet for smoke control. By controlling the lid of the outlet, the temperature inside the shrimp chamber i.e. the upper chamber could be controlled. Another small hole on the top was used to provide a sensitive thermometer to measure the temperature inside the chamber.

Preparation procedure of smoked shrimp (in laboratory) Good quality fresh raw shrimps of 4 different specices were directly transported from Koyra, Khulna to BAU in an insulated box with ice (1:1). Fish larvae, small fish, other shrimps, sea snails and other mollusks were separated properly and discarded, then specific shrimp specices were selected to prepare inproved smoked shrimp. For smoking of shrimps, wood and saw dust were burnt to produce smoke in 
smoking kiln. The smoke temperature varied between 60 to $70^{\circ} \mathrm{C}$, which led to partially dry the shrimps within 4-5 hours. The saw dust used for smoking procedure were of black berry, mahogany, lebbeck, wood apple etc. tree and partially dried before using in the kiln. The saw dust was collected from a local saw-mill. The steps of smoked shrimp preparation is mentioned in Flow chart-1.

\section{Storage of smoked shrimp}

Certain amount of each improved smoked shrimp samples were kept in non-sealed, air tight and vacuum sealed packages [Plate-2 (c-e)]. The traditionally prepared smoked shrimp samples (purchased from Koyra, Khulna) were also packed as done with improved samples. Then all the packed samples were stored at refrigeration temperature $\left(5\right.$ to $\left.8^{\circ} \mathrm{C}\right)$ for further analysis.

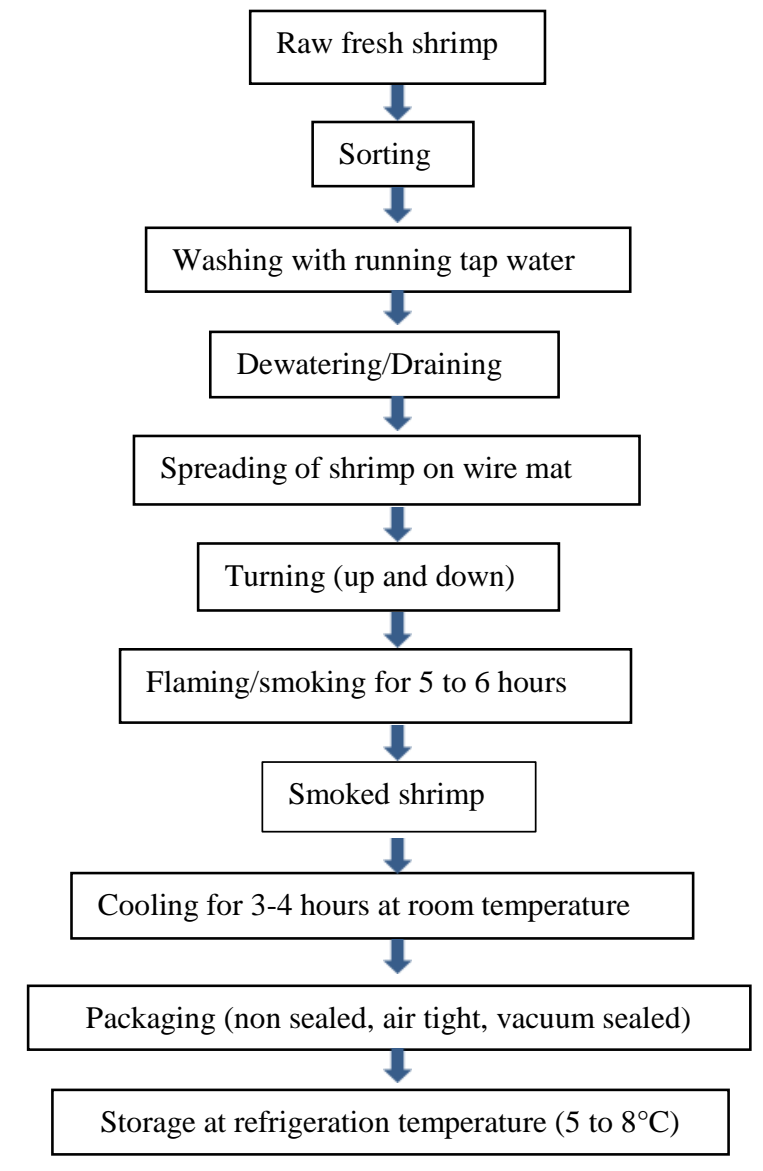

Flow chart 1. Steps followed in the laboratory to prepare improved smoked shrimp

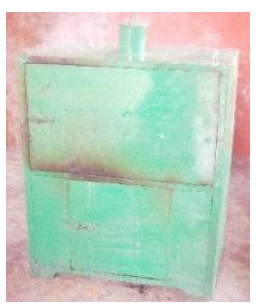

(a)

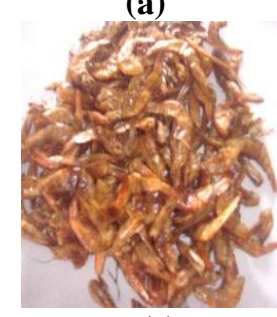

(c)

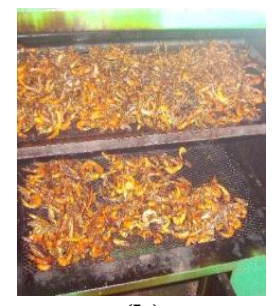

(b)

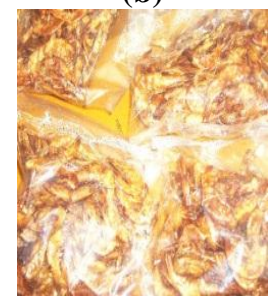

(d)

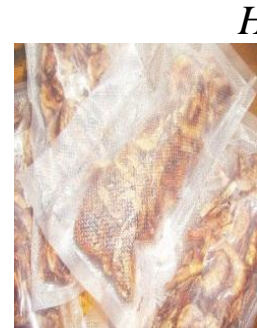

(e)

Plate 2. (a) Smoking kiln, (b) Smoking of shrims in smoking kiln, (c) Smoked shrimp in non sealed package, (d) Smoked shrimp in air tight package and (e) Smoked shrimp in vacuum package

\section{Organoleptic quality assessment}

For organoleptic quality assessment, sensory methods are considered to be the most useful. Since human beings are capable to detect defects from visual signs of deterioration such as loss of freshness and changes during storage. Sensory evaluation is considered as the most effective technique to assess fish freshness and quality deterioration (Martinsdóttir 2002; Alasalvar et al. 2011). Therefore, organoleptic characteristics (general appearance, taste, flavor, texture, and color) of the smoked shrimp were examined by this methods (through sight, touch, taste, smelling, etc.). The evaluation methods used in this study were based on the one that is currently in use in various institution of the world (Larmond, 1977). The organoleptic and physical characteristics like color, texture and odor when broken etc. were evaluated in the Department of Fisheries Technology, BAU by a five member's panel. The grading of smoked shrimps was done using the score on the characteristics that has been described by AOAC (1990) as freshness grade for fishery products with certain modification as described in Table-1 and Table-2.

\section{Table 1. Grading of smoked shrimps}

\begin{tabular}{ccc}
\hline Grade & Points & Comments \\
\hline A & $<2$ & Excellent/ Acceptable \\
\hline B & 2 to $<5$ & Good/ Acceptable \\
\hline C & 5 & $\mathrm{Bad} /$ Rejected \\
\hline
\end{tabular}

Table 2. Determination of defect points of smoked shrimp

\begin{tabular}{llcc}
\hline Characteristics & \multicolumn{1}{c}{ Defect } & $\begin{array}{c}\text { Defect } \\
\text { point }\end{array}$ & Grade \\
& a) Bright red color & 1 & Excellent \\
1. Color of & b) Dark red color & 2 & Acceptable \\
smoked shrimp & c) Brownish & 3 & Acceptable \\
& d) Whitish & 5 & Rejected \\
\hline \multirow{5}{*}{ 2. Odor } & a) Strong smoky & 1 & Excellent \\
& sweet odor & & Acceptable \\
& $\begin{array}{l}\text { b) Mild smoky odor } \\
\text { c) Neutral odor }\end{array}$ & 2 & Acceptable \\
& d) Rancid off odor & 5 & Rejected \\
\hline a). Crisp, fragile & 1 & Excellent \\
& $\begin{array}{l}\text { texture } \\
\text { b). Fragile texture }\end{array}$ & 2 & Acceptable \\
c). Less fragile and & 4 & Acceptable \\
& elastic texture & & \\
d). Powdery structure & 5 & Rejected \\
with whitish fungal & & \\
\hline growth & & \\
\hline
\end{tabular}




\section{Biochemical analysis}

\section{Proximate composition analysis}

Proximate composition analysis of moisture, crude protein, lipid and ash of smoked shrimp samples were done according to the methods as described in AOAC (1990) with certain modifications.

\section{Total Volatile Base- Nitrogen (TVB-N) value} determination

TVB-N was determined according to the methods given in AOAC (1984) with certain modification.

\section{Determination of microbial load}

Aerobic plate count was done by spread plate count method. Peptone diluent $(0.2 \%)$ and plate count agar of commercial preparations or prepared in the laboratory as per method given in Cowan and Steel's Manual for the Identification of Medical Bacteria (edited by Barraw and Feltheam, 1993) were used in the shelf life study of smoked shrimp. Aerobic plate count was done by consecutive decimal dilution technique. According to International Standard Organization (ISO, 1965) APC was calculated by the following formula:

$$
\mathrm{APC} / \mathrm{g}=\mathrm{C} \times \mathrm{D} \times 10 / \mathrm{S} \mathrm{CFU} / \mathrm{g}
$$

Where,

$\mathrm{C}=$ Number of colonies found
$\mathrm{D}=$ Dilution factor

$\mathrm{S}=$ Weight of sample in grams

$\mathrm{CFU}=$ Colony forming unit

\section{Statistical analysis}

To analyze the data, one-way analysis of variance and the general linear model using Windows for SPSS 9.0 were used. The Duncan's New Multiple Range Test (DMRT) was used to find the significant differences between storage periods.

\section{Results and Discussion \\ Organoleptic quality assessment of smoked shrimps}

On the basis of color, odor, texture and overall other quality aspects, the organoleptic qualities of traditional and improved smoked shrimps were evaluated and the results are presented in Table-3. The smoked shrimp of bright red color, strong smoky odor and crisp, fragile texture is considered excellent and preferred by the consumers most. In the present study, the color of traditional smoked chali ranged from dark red to reddish color and the odor was mild smoky. The texture of traditional smoked chali was fragile to elastic which showed the medium quality of the product. The average defect point of the traditional smoked Chali was 2.33. On the basis of the organoleptic observation, traditional smoked chali was good/acceptable.

Table 3. Organoleptic quality of traditional smoked chali and improved smoked samples of four different shrimp species

\begin{tabular}{|c|c|c|c|c|c|}
\hline Sample name & Characteristics & Defect Characteristics & $\begin{array}{l}\text { Defect } \\
\text { points }\end{array}$ & $\begin{array}{c}\text { Average Defect } \\
\text { Points }\end{array}$ & $\begin{array}{c}\text { Grade/ } \\
\text { Comments }\end{array}$ \\
\hline \multirow{3}{*}{$\begin{array}{l}\text { Traditionally } \\
\text { smoked Chali }\end{array}$} & Color & Reddish color & 3 & \multirow{3}{*}{2.33} & \multirow{3}{*}{$\begin{array}{c}\text { B } \\
\text { Good/Acceptable }\end{array}$} \\
\hline & Odor & Mild smoky odor & 2 & & \\
\hline & Texture & Fragile texture & 2 & & \\
\hline \multirow{3}{*}{$\begin{array}{c}\text { Improved smoked } \\
\text { Horina }\end{array}$} & Color & Bright red color & 1 & \multirow{3}{*}{1.0} & \multirow{3}{*}{$\begin{array}{c}\text { A } \\
\text { Excellent }\end{array}$} \\
\hline & Odor & Strong smoky odor & 1 & & \\
\hline & Texture & Crisp fragile texture & 1 & & \\
\hline \multirow{3}{*}{$\begin{array}{c}\text { Improved smoked } \\
\text { Chali }\end{array}$} & Color & Bright red color & 1 & \multirow{3}{*}{1.0} & \multirow{3}{*}{$\begin{array}{c}\text { A } \\
\text { Excellent }\end{array}$} \\
\hline & Odor & Strong Smoky odor & 1 & & \\
\hline & Texture & Crisp fragile texture & 1 & & \\
\hline \multirow{3}{*}{$\begin{array}{c}\text { Improved smoked } \\
\text { Chaka }\end{array}$} & Color & Bright red color & 1 & \multirow{3}{*}{1.33} & \multirow{3}{*}{$\begin{array}{c}\text { A } \\
\text { Excellent }\end{array}$} \\
\hline & Odor & Strong Smoky odor & 1 & & \\
\hline & Texture & Fragile texture & 2 & & \\
\hline \multirow{3}{*}{$\begin{array}{c}\text { Improved smoked } \\
\text { Khogda }\end{array}$} & Color & Dark red color & 2 & \multirow{3}{*}{1.33} & \multirow{3}{*}{$\begin{array}{c}\text { A } \\
\text { Excellent }\end{array}$} \\
\hline & Odor & Strong smoky odor & 1 & & \\
\hline & Texture & Crisp fragile texture & 1 & & \\
\hline
\end{tabular}

Among the improved smoked shrimps, except Khogda, the other three shrimp species showed preferable bright red color after smoking. Khogda showed dark red color. The organoleptic characteristics of improved smoked Horina and Chali were better than those of traditionally smoked Chali. The texture of the improved smoked shrimp was crisp and fragile which was achieved through reduction of moisture properly. The average defect points of improved smoked Horina, Chali, Chaka, and Khogda were 1.0, 1.0, 1.33 and 1.33 , respectively. Differences in the defect points of improved smoked shrimps might be due to the differences in the quality (size, freshness etc.) of the raw materials.

Changes in organoleptic characteristics of traditional and improved smoked chali during storage at refrigeration temperature

By sensory methods (through sight, touch, taste, smelling, etc.) the organoleptic characteristics (general appearance, taste, flavor, texture, and color) of the smoked shrimps were examined. On the basis of the method currently used by Fish Inspection and Quality Control (FIQC) of DoF, the present study was done with slight modifications, which are summarized in Table-4. In the case of non-sealed package, the sensory quality of traditional smoked shrimp was good up to 60 days at refrigeration temperature, whereas the quality of improved smoked shrimp were good till 90 days. In airtight package, the smoked shrimps were more stable than the samples stored in non-sealed package and the improved smoked chali was acceptable in this pack until 120 days and the traditional smoked chali up to 90 days. On the other hand, in vacuum sealed package the sensory quality of smoked shrimps remained very good even after storage of 120 days. Smoked shrimps stored in vacuum sealed package scored quite near to those of smoked shrimps on " 0 " days of storage. During the storage, the changes in color of different shrimp samples from whitish to brownish might occurred 
due to the oxidation of lipid. Among the samples stored in three different packages, shrimps stored in non-sealed package were found more susceptible to lipid oxidation and the case of the oxidation might be due to the action of air over the samples.

Haq et al. (2008) carried out a comparative study on the shelf life of smoked shrimp products in different storage conditions. They used polythene bag, gunny bag, hogla made basket for storing both traditional and improved smoked shrimp at room temperature $\left(28\right.$ to $\left.30^{\circ} \mathrm{C}\right)$ for 4 months. According to that study, the traditional and improved smoked shrimps were bright red in color, odor was sweet and the texture was fragile-crispy. With the progress of storage time, the smoked shrimp absorbed atmospheric air, become rancid by hydrolysis. The product stored in polythene bag was comparatively in better condition than other two bags as polythene bag is less permeable of air than other two. These results are quite similar to the finding of the present study.

Nahid et al. (2017) conducted a comparative study on the shelf-life quality of salt and garlic treated smoke-dried Xenentodon cancila under different storage conditions. At the beginning of storage, all the sensory parameters of S+G (salt + garlic) treated smoke-dried fish samples were rated as good based on the grading scale. Moreover, no broken parts of the experimental fishes after smoke-drying process were found. The highest mean of general acceptability score was 8.90 (9-point ascending scale to evaluate changes in color, dor, texture, general appearance and mean of general acceptability score in freshly process $\mathrm{S}+\mathrm{G}$ treated smokedried fish samples). The mean of general acceptability score decreased as storage-duration increased and the acceptability score $<3.5$ is considered as rejected or spoiled for $\mathrm{S}+\mathrm{G}$ treated smoke-dried products during room and refrigeration storage. The mean of general acceptability score of the end product of $\mathrm{S}+\mathrm{G}$ treated smoke dried $X$. cancila fish was 3.37 (14 months) and 3.36 (24 months) for room and refrigeration storage, respectively. The reduction in the sensory qualities with increase in storage period of processed fish could be attributed to higher activities of the spoilage agents which is in agreement with the findings of Olatunde et al (2013) and Daramola et al. (2007) who observed the changes during storage of crustaceans (oyster and shrimps) and revealed quality loss during storage both at ambient and chilling temperature. Similarly, Llobreda et al. (1986) and Reilly and Dela-cruz (1986) also studied the quality changes during storage of crustaceans (oyster and shrimps) and found quality losses both at ambient and chilling temperature. All these results are in an agreement with the present study.

Table 4. Changes in organoleptic characteristics of traditionally smoked chali and improved smoked chali during storage at refrigeration temperature $\left(5\right.$ to $\left.8^{\circ} \mathrm{C}\right)$ in different packages

\begin{tabular}{|c|c|c|c|c|c|c|}
\hline \multirow{3}{*}{$\begin{array}{l}\text { Days of } \\
\text { storage }\end{array}$} & \multicolumn{6}{|c|}{ Characteristics } \\
\hline & \multicolumn{2}{|c|}{ Non-sealed pack } & \multicolumn{2}{|c|}{ Air tight pack } & \multicolumn{2}{|c|}{ Vacuum pack } \\
\hline & $\begin{array}{c}\text { Traditional } \\
\text { smoked Chali }\end{array}$ & $\begin{array}{c}\text { Improved } \\
\text { smoked Chali }\end{array}$ & $\begin{array}{c}\text { Traditional } \\
\text { smoked Chali }\end{array}$ & $\begin{array}{c}\text { Improved } \\
\text { smoked Chali }\end{array}$ & $\begin{array}{c}\text { Traditional } \\
\text { smoked Chali }\end{array}$ & $\begin{array}{c}\text { Improved smoked } \\
\text { Chali }\end{array}$ \\
\hline \multirow{3}{*}{0} & Bright red color & Bright red color & Bright red color & Bright red color & Bright red color & Bright red color \\
\hline & $\begin{array}{l}\text { Strong smoky } \\
\text { sweet odor }\end{array}$ & $\begin{array}{l}\text { Strong smoky } \\
\text { sweet odor }\end{array}$ & $\begin{array}{l}\text { Strong smoky } \\
\text { sweet odor }\end{array}$ & $\begin{array}{l}\text { Strong smoky } \\
\text { sweet odor }\end{array}$ & $\begin{array}{l}\text { Strong smoky } \\
\text { sweet odor }\end{array}$ & $\begin{array}{l}\text { Strong smoky sweet } \\
\text { odor }\end{array}$ \\
\hline & $\begin{array}{l}\text { Crisp and fragile } \\
\text { texture }\end{array}$ & $\begin{array}{l}\text { Stringy and fragile } \\
\text { texture }\end{array}$ & $\begin{array}{l}\text { Crisp and fragile } \\
\text { texture }\end{array}$ & $\begin{array}{l}\text { Stringy and } \\
\text { fragile texture }\end{array}$ & $\begin{array}{l}\text { Crisp and fragile } \\
\text { texture }\end{array}$ & $\begin{array}{l}\text { Stringy and fragile } \\
\text { texture }\end{array}$ \\
\hline \multirow{3}{*}{15} & Bright red color & Bright red color & Bright red color & Bright red color & Bright red color & Bright red color \\
\hline & $\begin{array}{l}\text { Strong smoky } \\
\text { sweet odor }\end{array}$ & $\begin{array}{l}\text { Strong smoky } \\
\text { sweet odor }\end{array}$ & $\begin{array}{l}\text { Strong smoky } \\
\text { sweet odor }\end{array}$ & $\begin{array}{l}\text { Strong smoky } \\
\text { sweet odor }\end{array}$ & $\begin{array}{l}\text { Strong smoky } \\
\text { sweet odor }\end{array}$ & $\begin{array}{l}\text { Strong smoky sweet } \\
\text { odor }\end{array}$ \\
\hline & $\begin{array}{l}\text { Crisp and fragile } \\
\text { texture }\end{array}$ & $\begin{array}{l}\text { Stringy and fragile } \\
\text { texture }\end{array}$ & $\begin{array}{l}\text { Crisp and fragile } \\
\text { texture }\end{array}$ & $\begin{array}{l}\text { Stringy and } \\
\text { fragile texture }\end{array}$ & $\begin{array}{l}\text { Stringy and } \\
\text { fragile texture }\end{array}$ & $\begin{array}{l}\text { Stringy and fragile } \\
\text { texture }\end{array}$ \\
\hline \multirow{4}{*}{30} & Mild red color & Dark red color & Dark red color & Dark red color & Bright red color & Bright red color \\
\hline & Mild smoky odor & Mild smoky odor & Strong smoky & Strong smoky & Strong smoky & Strong smoky sweet \\
\hline & & Stringy and fragile & sweet odor & sweet odor & sweet odor & odor \\
\hline & & texture & $\begin{array}{l}\text { Crisp and fragile } \\
\text { texture }\end{array}$ & $\begin{array}{l}\text { Stringy and } \\
\text { fragile texture }\end{array}$ & $\begin{array}{l}\text { Stringy and } \\
\text { fragile texture }\end{array}$ & $\begin{array}{l}\text { Stringy and fragile } \\
\text { texture }\end{array}$ \\
\hline \multirow{4}{*}{60} & Brownish color & Mild red color & Reddish color & Reddish color & Dark red color & Bright red color \\
\hline & Neutral odor & Mild smoky odor & Mild smoky odor & Mild smoky odor & Strong smoky & Strong smoky sweet \\
\hline & Fragile texture & Crispa, fragile & Fragile texture & Fragile texture & sweet odor & odor \\
\hline & with powder & texture & & & $\begin{array}{l}\text { Crisp and fragile } \\
\text { texture }\end{array}$ & $\begin{array}{l}\text { Stringy and fragile } \\
\text { texture }\end{array}$ \\
\hline \multirow{3}{*}{90} & $*$ Whitish color & Brownish color & Brownish color & Reddish color & Mild red color & Dark red color \\
\hline & Rancid, off odor & Neutral odor & Neutral odor & Mild smoky odor & Mild smoky odor & Strong smoky sweet \\
\hline & $\begin{array}{l}\text { Powdery structure } \\
\text { with whitish } \\
\text { fungal colony }\end{array}$ & $\begin{array}{l}\text { Less fragile and } \\
\text { some elastic } \\
\text { texture }\end{array}$ & Fragile texture & Fragile texture & $\begin{array}{l}\text { Elastic structure } \\
\text { of muscle }\end{array}$ & $\begin{array}{l}\text { odor } \\
\text { Stringy and fragile } \\
\text { texture }\end{array}$ \\
\hline \multirow{3}{*}{120} & & * Whitish color & $*$ Whitish color & Brownish color & Brownish color & Reddish color \\
\hline & & Rancid, off odor & Rancid, off odor & Neutral odor & Neutral odor & Mild smoky odor \\
\hline & - & $\begin{array}{l}\text { Powdery structure } \\
\text { with whitish } \\
\text { fungal growth - }\end{array}$ & $\begin{array}{l}\text { Powdery structure } \\
\text { with whitish } \\
\text { fungal colony }\end{array}$ & $\begin{array}{l}\text { Less fragile and } \\
\text { some elastic } \\
\text { texture }\end{array}$ & $\begin{array}{l}\text { Crisp texture with } \\
\text { powder }\end{array}$ & $\begin{array}{l}\text { Crispa, fragile } \\
\text { texture }\end{array}$ \\
\hline
\end{tabular}

* indicates the stage of rejection in storage period and

- indicates the empty pack, after rejection of the samples before $120^{\text {th }}$ day of storage 
Changes in biochemical and microbiological parameters of smoked shrimps at refrigeration temperature

The quality parameters of a products are affected by the preparation procedure of the product, storage temperature, packing materials etc. The changes in the biochemical and microbiological parameters of smoked shrimps (both traditional and improved) during storage at refrigeration temperature $\left(5\right.$ to $\left.8^{\circ} \mathrm{C}\right)$ under different packing conditions are presented in Table-5.

\section{Changes in biochemical parameters \\ Moisture}

The moisture content of traditional smoked Chali was $17.53 \pm 0.11 \%$ at the initial stage of storage. In improved smoked Horina, Chali, Chaka and Khogda, the moisture contents were $15.36 \pm 0.05 \%, 14.22 \pm 0.13 \%, 16.02 \pm 0.02 \%$ and $16.15 \pm 0.12 \%$, respectively. During storage in different packages, the moisture content $(\%)$ of all the species of smoked shrimps increased with the lapse of storage period. After 15 days of storage, the moisture contents (\%) of traditional smoked Chali were $19.94 \pm 0.13,18.95 \pm 0.13$ and $17.55 \pm 0.12$ in non-sealed, air tight and vacuum sealed packs, respectively which increased to $32.88 \pm 0.21,22.75 \pm 0.12$ and $18.83 \pm 0.21$, respectively after storage period of 120 days at refrigeration temperature. In case of improved smoked Chali, Horina, Chaka and Khogda, similar increasing trend in moisture content (\%) was followed (Table-5). The moisture contents $(\%)$ were $18.53 \pm 0.13,16.45 \pm 0.14$ and $14.29 \pm 0.12$ in non-sealed, air tight and vacuum sealed improved smoked Chali after $30^{\text {th }}$ day of storage, with the progress of storage period moisture content of these samples increased to $26.56 \pm 0.14,18.09 \pm 0.11$ and $14.78 \pm 0.15$, respectively on $90^{\text {th }}$ day of storage indicating the slower rate of moisture increase of the smoked shrimp samples both in air tight and vacuum sealed packages.

\section{Protein}

The protein content of traditional smoked Chali was $61.18 \pm 0.91 \%$ and in improved smoked Horina, Chali, Chaka and Khogda, the protein contents were $63.70 \pm 0.55 \%$, $64.05 \pm 0.41 \%, \quad 62.15 \pm 0.54 \%$ and $63.11 \pm 0.41 \%$, respectively. Protein content (\%) of all the species of smoked shrimps stored in different packages decreased with the progress of storage period. After 15 days of storage at refrigeration temperature, the protein contents (\%) of traditional smoked Chali was 58.42 $\pm 0.34,59.39 \pm 0.66$ and $60.21 \pm 0.45$ in non-sealed, air tight and vacuum sealed packages, respectively which decreased to $44.78 \pm 0.22$, $53.14 \pm 0.24$ and $54.91 \pm 0.39$, respectively after 90 days of storage period. For all other improved smoked samples similar decreasing trend in protein content $(\%)$ was observed (Table-5). The protein contents were $61.97 \pm 0.54 \%$, $62.15 \pm 0.57 \%$ and $62.89 \pm 0.51 \%$ in non-sealed, air tight and vacuum sealed improved smoked Horina on $15^{\text {th }}$ day of storage, with the lapse of storage time protein content of these samples decreased to $45.44 \pm 0.33 \%, 53.11 \pm 0.55 \%$ and $56.05 \pm 0.51 \%$ on $120^{\text {th }}$ day of storage indicating the faster rate of protein decrease in the smoked shrimp samples stored in non-sealed packages.

\section{Lipid}

At the beginning of storage, the lipid contents were $9.24 \pm 0.05 \%, 10.05 \pm 0.06 \%, 9.85 \pm 0.04 \%, 9.96 \pm 0.06 \%$ and $9.36 \pm 0.06 \%$ in traditional smoked Chali, improved smoked Horina, Chali, Chaka and Khogda, respectively. During storage, the lipid content $(\%)$ of all the species of smoked shrimps decreased with the progress in storage period. The lipid contents (\%) of traditional smoked Chali were $8.75 \pm 0.04,9.11 \pm 0.02$ and $9.18 \pm 0.03$ in non-sealed, air tight and vacuum sealed packages, respectively on $15^{\text {th }}$ day of storage which decreased to $6.27 \pm 0.10,6.79 \pm 0.08$ and $6.79 \pm 0.08$ after 120 days of storage at refrigeration temperature. A similar decreasing trend in lipid content (\%) was found in all other improved smoked samples (Table-5). The lipid contents $(\%)$ were $9.73 \pm 0.05,9.88 \pm 0.06$ and $9.94 \pm 0.01$ in non-sealed, air tight and vacuum sealed improved smoked Chaka on $15^{\text {th }}$ day of storage. With the progress of storage period, lipid content of these samples decreased to $7.96 \pm 0.05,9.01 \pm 0.07$ and $9.33 \pm 0.05$ after $90^{\text {th }}$ day of storage indicating the slower rate of lipid oxidation of the smoked shrimp samples both in air tight and vacuum sealed packages.

\section{Ash}

The ash contents were $12.52 \pm 0.09 \%, 11.38 \pm 0.08 \%$, $11.06 \pm 0.06 \%, 11.79 \pm 0.07 \%$ and $12.14 \pm 0.04 \%$ in traditional smoked Chali, improved smoked Horina, Chali, Chaka and Khogda, respectively. Ash content (\%) gradually increased with the progress of storage period in all species of smoked shrimps. The ash contents $(\%)$ of traditional smoked Chali were $14.52 \pm 0.05,13.81 \pm 0.09$ and $13.52 \pm 0.12$ stored in non-sealed, air tight and vacuum sealed packages, respectively on $30^{\text {th }}$ days of storage at refrigeration temperature, which increased to $19.11 \pm 0.07,16.46 \pm 0.06$ and $15.89 \pm 0.11$ after storage period of 120 days. A similar increasing trend in ash content (\%) was observed for all other improved smoked samples- (Table-5). The ash contents were $12.88 \pm 0.05 \%, 12.49 \pm 0.07 \%$ and $12.42 \pm 0.05 \%$ in non-sealed, air tight and vacuum sealed improved smoked khogda on $15^{\text {th }}$ day of storage, with the lapse of storage time ash content of these samples decreased to $15.96 \pm 0.07 \%, 14.52 \pm 0.09 \%$ and $14.00 \pm 0.08 \%$ on $90^{\text {th }}$ day of storage indicating the faster rate of increase in ash content of the smoked shrimp samples in non-sealed packages.

\section{TVB-N Value}

Initially, the TVB-N values were $15.83 \pm 0.08,12.86 \pm 0.07$, $12.23 \pm 0.11, \quad 14.05 \pm 0.13$ and $13.14 \pm 0.10(\mathrm{mg} / 100 \mathrm{~g})$ in traditional smoked Chali, improved smoked Horina, Chali, Chaka and Khogda, respectively. The TVB-N values of all the species of smoked shrimps increased with the progress of storage period. The TVB-N values of traditional smoked Chali were $18.69 \pm 0.09, \quad 17.73 \pm 0.11$ and $17.12 \pm 0.10$ $(\mathrm{mg} / 100 \mathrm{~g})$ in non-sealed, air tight and vacuum sealed packages, respectively on $15^{\text {th }}$ day of storage which increased to $35.33 \pm 0.12, \quad 30.15 \pm 0.10$ and $25.72 \pm 0.11$ $(\mathrm{mg} / 100 \mathrm{~g})$ after 90 days of storage at refrigeration temperature. A similar increasing trend in TVB-N values was found for all other samples (Table-5). Among them, the TVB-N values were reported to be $18.78 \pm 0.12,17.34 \pm 0.12$ and $15.42 \pm 0.15(\mathrm{mg} / 100 \mathrm{~g})$ in non-sealed, air tight and vacuum sealed improved smoked horina on $30^{\text {th }}$ day of storage, with the progress of storage period the TVB-N values of these samples increased to $32.84 \pm 0.11,29.89 \pm 0.12$ and $25.94 \pm 0.14(\mathrm{mg} / 100 \mathrm{~g})$ after 120 days of storage indicating that the rate of increase in TVB-N values in air tight and vacuum sealed packages is slower than in nonsealed package. 


\section{Changes in microbiological parameter} Aerobic plate count (APC) of bacteria

At the initial stage of storage, APC of bacteria were $3.60 \mathrm{x}$ $10^{3}, 9.80 \times 10^{2}, 4.30 \times 10^{2}, 2.05 \times 10^{3}$ and $1.12 \times 10^{3} \mathrm{CFU} / \mathrm{g}$ in traditional smoked Chali, improved smoked Horina, Chali, Chaka and Khogda, respectively at refrigeration temperature. During storage in different packages, APC of all the species of smoked shrimps increased with the progress of storage period. After storage period of 15 days, the APC of traditional smoked Chali were $4.40 \times 10^{4}, 1.62 \times 10^{4}$ and 8.80 $\mathrm{x} 10^{3} \mathrm{CFU} / \mathrm{g}$ in non-sealed, air tight and vacuum sealed packages, respectively which increased to $3.16 \times 10^{7}, 2.07 \mathrm{x}$ $10^{6}$ and $3.10 \times 10^{5} \mathrm{CFU} / \mathrm{g}$ after storage period of 120 days at refrigeration temperature. In case of improved smoked Chali, Horina, Chaka and Khogda, a similar increasing trend in APC of bacteria was observed (Table-5). Among different smoked shrimp samples, APC of bacteria were $1.72 \times 10^{4}, 8.50 \times 10^{3}$ and $3.10 \times 10^{3} \mathrm{CFU} / \mathrm{g}$ in non-sealed, air tight and vacuum sealed improved smoked Chaka on $15^{\text {th }}$ day of storage. With the progress of storage period, APC of these samples increased to $1.18 \times 10^{7}, 6.20 \times 10^{5}$ and $2.24 \times 10^{5} \mathrm{CFU} / \mathrm{g}$ after 90 days of storage indicating the slower rate of increase in APC count of the smoked shrimp samples both in air tight and vacuum sealed packages.

Hoq et al (2003) studied the nutritional qualities of smoked shrimp from the Sundarbans mangrove area, Bangladesh. They observed in their 90 days of storage quality study that, moisture level increased to $24 \%$ from initial $13 \%$ and the protein content of raw shrimp was $14.51 \%$, after smoking the protein content was $68.08 \%$ due to loss of about $60 \%$ moisture. After one month storage, protein content reduced to $64.48 \%$. The protein percentage further reduced to $57.17 \%$ after 60 days and at $90^{\text {th }}$ day it stands at $52 \%$ due to gradual increase of moisture content. Lipid content gradually increased to $11.66 \%$ from $6.88 \%$. Proximate composition and bacterial load study in market sample revealed increased moisture level $(19.51 \%)$ and decreased protein content $(60.83 \%)$ with a microbial load of $6.5 \times 10^{4} \mathrm{CFU} / \mathrm{g}$. TVBN value increased with storage time from $22.75 \%$ at " 0 "day to $29.33 \%$ at $90^{\text {th }}$ day. Total bacterial counts of the smoked product increased to $1.41 \times 10^{7} \mathrm{CFU} / \mathrm{g}$ from an initial $2.46 \times 10^{4} \mathrm{CFU} / \mathrm{g}$ over 90 days. These results are quite similar to the findings of present study.

A comparative study on the shelf life of smoked shrimp products in different storage conditions was carried out by Haq et al. (2008), which was in agreement with the present study. The study was performed at room temperature $\left(28 \sim 30^{\circ} \mathrm{C}\right.$ ) and the smoked shrimp (Chali; Metapeneous brevicornis) was stored at polythene bag, gunny bag and hogla made basket. Different quality parameters of smoked shrimps were studied for 4 months at 15 days interval. In their 4 months study, moisture level increased from $11.87 \pm 0.51$ to $25.48 \pm 0.28,26.53 \pm 0.12$ and $29.41 \pm 0.25 \%$ in polythene bag, gunny bag and hogla made basket, respectively. The protein content reduced from $66.08 \pm 0.76$ to $51.32 \pm 0.26,51.89 \pm 0.42$ and $46.80 \pm 0.50$ in three above mentioned bags, respectively. Lipid content also gradually
Hossain et al., 2020

decreased from $9.43 \pm 0.65$ to $9.35 \pm 0.41,9.13 \pm 0.51$ and $8.98 \pm 0.46$, respectively. TVB-N value increased with the lapse of storage time from 13.42 to $28.60,32.45$ and 34.06 , respectively for the samples stored in above mentioned bags. Nahid et al (2017) conducted a study to determine of shelf life quality of three smoke-dried freshwater fishes in refrigerated storage. It was found that, moisture, protein, fat, ash and TVB-N value of freshly processed smoke-dried chapila, kaika and baim fish samples varied in the range of $8.22 \%$ to $12.36 \%, 45.25 \%$ to $74.85 \%, 5.25 \%$ to $32.05 \%, 8.31$ to $10.83 \%, 6.39$ to $11.08 \mathrm{mgN} / 100 \mathrm{~g}$ respectively. During smoke-drying, the percentage of moisture content decreased whereas protein, fat and ash content increased due to water loss. Later during storage, it was observed that moisture and TVB-N value gradually increased whereas protein and fat content decreased at refrigeration storage condition. This increase in moisture content can be attributed to absorption of moisture from the surrounding since there was no redrying during storage (Daramola et al., 2007). During storage, the protein content decreased significantly with the time due to water soluble protein diffused out to the surrounding for exosmosis (Hasan et al., 2013). This could be due to gradual degradation of initial crude protein to more volatile products such as total volatile bases, hydrogen sulphide and ammonia (Eyo, 2001). Similar drop in protein concentration was reported for Heterobranchus longifilis (Abolagba et al., 2008). At refrigeration temperature, reduction in lipid content over the storage period may be attributed to oxidation of poly-unsaturated fatty acids contained in the fish tissue to products such as peroxides, aldehydes, ketones and free fatty acids (Horner, 1992). Egbal et al. (2013) stated that decrease in fat during storage may also be due to the effect of packaging and storage condition. The increase in TVB-N value may be due to microbial activity, storage temperature, and absorption of moisture. Total Viable Counts (TVC) in terms of CFU/g of bacteria in smoke-dried chapila, kaika and baim fish samples were $3.3 \times 10^{4} \mathrm{CFU} / \mathrm{g}, \quad 3.6 \times 10^{4} \mathrm{CFU} / \mathrm{g}$ and $3.7 \times 10^{3} \mathrm{cfu} / \mathrm{g}$, respectively at the initial stage of storage of the fishes. TVC were found to be increased with storage at refrigeration temperature. As the duration of storage increased, the processed fish samples may absorb small amounts of moisture from surrounding atmosphere providing enabling environment for microbial growth (Eyo, 2006). All these literatures are in agreement with the findings in the present study accept the decreasing trend in lipid.

\section{Conclusion}

On the basis of the obtained results the study could be concluded as- improved smoked shrimps can be stored in air tight package or vacuum package at refrigeration temperature $\left(5\right.$ to $\left.8^{\circ} \mathrm{C}\right)$ for 150 days or more without significant quality loss. Improved smoked shrimp showed the longer shelf life compared to the traditional smoked shrimps. Among three different packages, non sealed is less effective than air tight or vacuum sealed packages for storing smoked shrimps. 
Table 5. Changes in the biochemical and microbiological parameters of smoked shrimps during storage at refrigeration temperature $\left(5\right.$ to $\left.8^{\circ} \mathrm{C}\right)$ in different packs

\begin{tabular}{|c|c|}
\hline Sample name & Packing condition \\
\hline & \\
\hline & \\
\hline & \\
\hline & \\
\hline & Non sealed pack \\
\hline & \\
\hline & \\
\hline & \\
\hline & \\
\hline & \\
\hline Traditional & \\
\hline & Air tight pack \\
\hline & \\
\hline & \\
\hline & \\
\hline & \\
\hline & \\
\hline & Vacuum sealed pack \\
\hline & \\
\hline & \\
\hline & \\
\hline & \\
\hline & \\
\hline & Non sealed pack \\
\hline & \\
\hline & \\
\hline & \\
\hline & \\
\hline & \\
\hline $\begin{array}{l}\text { Improved } \\
\text { mod }\end{array}$ & \\
\hline Smoked Horına & Air tight pack \\
\hline & \\
\hline & \\
\hline & \\
\hline & \\
\hline & \\
\hline & Vacuum sealed pack \\
\hline & \\
\hline & \\
\hline & \\
\hline & \\
\hline & \\
\hline & Non sealed pack \\
\hline & \\
\hline & \\
\hline & \\
\hline & \\
\hline & \\
\hline Improved & \\
\hline & Air tight pack \\
\hline & \\
\hline & \\
\hline & \\
\hline & \\
\hline & \\
\hline & Vacuum sealed pack \\
\hline & \\
\hline & \\
\hline & \\
\hline & \\
\hline & \\
\hline & Non sealed pack \\
\hline & \\
\hline & \\
\hline & \\
\hline & \\
\hline & \\
\hline Improved & \\
\hline & Air tight pack \\
\hline & \\
\hline & \\
\hline & \\
\hline & \\
\hline & Vocuu colod no \\
\hline & vacuum sealed pack \\
\hline & \\
\hline & \\
\hline & \\
\hline & \\
\hline & \\
\hline & Non sealed pack \\
\hline & \\
\hline & \\
\hline & \\
\hline & \\
\hline & \\
\hline $\begin{array}{l}\text { Improved } \\
\end{array}$ & \\
\hline smoked Khogda & Air tight pack \\
\hline & \\
\hline & \\
\hline & \\
\hline & \\
\hline & \\
\hline & Vacuum sealed pack \\
\hline & \\
\hline & \\
\hline
\end{tabular}




\section{References}

Abolagba OJ, Osifo SJ (2008). The Effect of Smoking on the Chemical Composition and Keeping Qualities of Catfish (Heterobranchus bidorsalis) using Two Energy Sources. Journal of Agriculture Forestry and Fisheries 5(1):27-30.

Alasalvar C, Grigor JM, Ali Z (2011). Practical evaluation of fish quality by objective, subjective, and statistical testing. In: Alasalvar C, Shahidi F, Miyashita K, Wanasundara U, editors. Handbook of seafood quality, safety and health applications. New Delhi: Blackwell Publishing Ltd. p.13-29.

AOAC (1984). Official Methods of Analysis. Association of Official Analytical Chemists. 14th Edition, AOAC, Arlington.

AOAC (1990). Official method of analysis .Association of Official Agricultural Chemists W. Horwitz (Editor) 12th ED. Washington. D.C.

Clucas IJ, and Ward AR (1996). Post-harvest Fisheries Development: A Guide to Handling, Preservation, Processing and Quality. Chatham Maritime, Kent ME 4 4TB, United Kingdom.pp.258-71.

Daramola JA, Fasakin EA, Adeparusi EO (2007). Changes in physicochemical and sensory characteristics of smokedried fish species stored at ambient temperature. African Journal of Food, Agriculture, Nutrition and Development 7(6).

Egbal OA, Hawa TA, Kalthom EM (2013). Investigating the quality changes of hot smoked Clarias Lazera at refrigerated temperature $\left(5 \pm 1^{\circ} \mathrm{C}\right)$. Journal of Agriculture and Food Science 1(3):27-32.

Eyo AA (2001). Fish processing technology in the tropics, University of Ilorin Press.

Eyo AA (2006). Fish processing technology in the tropics. University of llorin Press. Haq M (2008). Studies on the improvement of quality of traditional smoked shrimp products of Bangladesh. M. S. Thesis, submitted in the Department of Fisheries Technology, Bangladesh Agricultural University, Mymensingh, 96 pp.

Haq M. Shikha FH, Hossain MI, Kamal M (2008). A comparative study on the shelflife of smoked shrimp products in different storage conditions. Journal of Bangladesh Socio Agricultural Science and Technology 5 (3\&4) : 19-24.

Hassan MN, Rahman M, Hossain MM, Nowsad AAKM, Hossain MB (2013). Post-Harvest Loss and Shelf Life of Traditionally Smoked Shrimp Products Produced in Bangladesh. World Journal of Fish and Marine Science 5 (1):14-19.
Hoq ME, Islam MN, Kamal M (2003). Nutritional qualities of smoked shrimp from the Sundarband mangrove area, Bangladesh. Pakistan Journal of Scientific and Industrial Research 46(5): 376-382.

Hoq ME., Zaher M., Islam1 MS and Alam MJ (2006). Smoking of shrimp and fish from coastal village of northwest Bangladesh. Bangladesh Journal of Fisheries Research, 10(2): 203-206

Horner WFA (1992). Preservation of fish by curing (drying, salting and smoking) In: Fish Processing Technology (edited by G. M. Hall). Chapman and Hall Glasgow, UK pp.61-62.

Jahncke ML (2008). A review: Processing parameters needed to control pathogens in cold smoked fish. International Smoked Seafood Conference. DOI: 10.4027/isscp.2008.04

Larmond E (1977). Laboratory methods for sensory evaluation of food. Research Branch, Canada Dept. of Agriculture Publication 1637.

Llobreda AT, Bukalacao ML, Sunaz N (1986). Effects of Storage on the Microbial Quality of Slipper oyster (Cassostera iredalei). In: Maclean JL, Izon LBD, Hosilus LV (Eds). The First Asian Fisheries Forum, Manilla, Philippines.

Martinsdóttir E (2002). Quality management of stored fish. In: Bremner A, editor. Safety and quality issues in fish processing. Hirtshals: Woodhead Publishing Ltd. p. 360378.

Nahid MN, Latifa GA, Chakraborty SC, Farid FB, Begum M (2017a). Comparative quality assessment of $X$ cancila (kaika) fish smoked with salt and garlic in different storage condition. European Journal of Biotechnology and Bioscience 5 (1): 18-25.

Nahid MN, Latifa GA, Chakraborty SC, Farid FB, Begum M (2017b). The determination of shelf life quality of three smoke-dried freshwater fishes in refrigeration storage. International Journal of Advanced Scientific Research 2 (1): 17-24.

Olatunde KA, Bamgbose O, Arowolo TA, George FOA, Bada BS (2013). Quality and shelf-life assessment of variously processed Catfish and Tilapia stored at ambient temperature. British Journal of Applied Science \& Technology 3(3):440-451.

Reilly AE, Dela-cruz D (1986). Post- harvest spoilage of shrimp (Penaeus monodon). In: Maclean JL, Dixon LB, Hossillus LV (Eds). The first Asian Fish Forum. Manilla, Phillipines. 